\title{
Introduksi Gen Sitrat Sintase Pseudomonas aeruginosa ke Nicotiana tabacum dan Jatropha curcas untuk Meningkatkan Toleransi terhadap Cekaman Aluminium
}

\section{Introduction of Pseudomonas aeruginosa Citrate Synthase Gene to Nicotiana tabacum and Jatropha curcas to Enhance Tolerance to Aluminum Stress}

\author{
Radite Tistama $^{1}$, Utut Widyastuti ${ }^{2}$, Suharsono ${ }^{2 *}$ \\ ${ }^{1}$ Balai Penelitian Sungei Putih, Pusat Penelitian Karet, PO Box 1415 Medan 20001 \\ ${ }^{2}$ Fakultas Matematika dan Ilmu Pengetahuan Alam, Institut Pertanian Bogor Jl. Dramaga, Bogor 16680 \\ *Email : sony.suharsono@yahoo.com
}

Diterima 20 Juli 2017 / Disetujui 27 Agustus 2017

\begin{abstract}
ABSTRAK
Cekaman aluminium merupakan faktor penghalang utama untuk pengembangan komoditas tanaman unggulan di lahan-lahan masam. Sintesis dan sekresi asam organik oleh akar merupakan salah satu mekanisme mengurangi cekaman aluminium. Penelitian ini bertujuan mengintroduksikan gen sitrat sintase bakteri $P$. aeruginosa (PaCS) ke dalam tanaman tembakau ( $N$. tabacum) dan Jatropha curcas. PaCS berhasil diintroduksi dengan batuan Agrobacterium tumefaciens baik ke dalam jaringan tembakau maupun J. curcas.. Toleransi tembakau transgenik ditandai dengan pertambahan panjang akar yang lebih tinggi dibanding tipe liarnya pada cekaman $0,3 \mathrm{mM} \mathrm{AlCl}$. Toleransi tembakau transgenik dapat mengurangi masuknya $\mathrm{Al}$ ke dalam jaringan akar. Sifat toleran gen $\mathrm{PaCS}$ diturunkan mengikuti Hukum Mendel. Persentase introduksi gen $P a C S$ ke dalam $J$. curcas hanya $1 \%$ dari jumlah eksplan yang ditranformasi.
\end{abstract}

Kata kunci : introduksi gen, sitrat sintase, cekaman aluminium, N. tabacum, J. curcas

\section{ABSTRACT}

Aluminum stress is the main obstacle for development of superior commodity in the acid area. Organic acid synthesis and secresion of it by root is one mechanism of aluminum tolerance. This research obtain to introduced citrate synthase of $P$. aeruginosa $(P a C S)$ into tabacco (N. tabacum ) and J. curcas. PaCS was introduced succesfully by Agrobacterium tumefaciens into tabacco and Jatropha. The tolerance of transgenic tabacco signed with the lenght increase of root that were higher than its wild type under $0,3 \mathrm{mM} \mathrm{AlCl} 3$ treatment. The transgenic tabacco capable to reduced the aluminum influx to root tissue. The character of $\mathrm{PaCS}$ gene was inherited followed Mendel's law. The precentange of $\mathrm{PaCS}$ gene introduction into J curcas was low only $1 \%$ from total explants.

Keywords : gene introduction, citrate synthase, aluminum strees, N. tabacum, J. curcas

\section{PENDAHULUAN}

Keracunan alumininum (Al) merupakan penyebab utama berkurangnya pertumbuhan dan produktivitas tanaman pertanian di tanah masam. Pada $\mathrm{pH}$ di bawah $5, \mathrm{Al}^{3+}$ merupakan bentuk yang dominan di dalam tanah dan beracun bagi banyak tanaman (Kochian et al. 2002), dan dalam konsentrasi mikromolar $\mathrm{Al}^{3+}$ dapat menghambat pertumbuhan akar hanya dalam beberapa jam. Aluminium mengganggu fungsi dinding sel, plasma, dan jalur signal transduksi hanya beberapa jam setelah akar dicekam $\mathrm{Al}$ (Poschenrieder et al. 2008).

Upaya meningkatkan daya hasil tanaman di lahan masam dapat dilakukan dengan meningkatkan toleransi tanaman terhadap $\mathrm{Al}$ dengan mengurangi kontak sel dengan $\mathrm{Al}$. Ma (2000) menyebutkan bahwa salah satu mekanisme toleransi tanaman terhadap $\mathrm{Al}$ adalah dengan mencegah Al masuk ke jaringan akar atau mendetoksifikasi Al yang sudah masuk di dalam sel dan kemudian mengeluarkannya. Tanaman 
dapat mendektosifikasi $\mathrm{Al}$ dengan mensintesis dan mensekresikan asam organik. Usaha untuk mendapatkan tanaman yang toleran $\mathrm{Al}$ telah dilakukan dengan mengekspresikan secara berlebih gen yang mengatur sintesis asam sitrat yaitu gen sitrat sintase (de la Fuente et al. 1997; Koyama et al. 2000; Anoop et al 2003).

Pseudomonas merupakan salah satu mikroba utama di dalam rhizosfer yang banyak digunakan berbagai proses seperti mengatasi cekaman oksidatif (Hassett et al. 1993), antimikroba (Chin-A-Woeng et al. 2003), dan pengkelat logam (Lemire et al. 2010). Beberapa spesies dalam genus ini juga sitrat (Buch et al. 2008) yang dikaitkan dengan toleransi bakteri ini terhadap cekaman Al (Mailloux et al. 2008; Lemire et al. 2010). Hal ini menjadi alasan para peneliti mengisolasi dan mengekspresikan gen sitrat sintase Pseudomonas ke dalam tanaman atau khamir (de la Fuente et al. 1997; Baron et al. 2008).

Tanaman yang banyak digunakan untuk model rekayasa genetik adalah Arabidopsis thaliana, Nicotiana bentamiana (Deng et al. 2009; Anggraito 2012) dan Nicotiana tabacum (de la Fuente et al. 1997; Hanum 2012). Hanum (2012) melaporkan bahwa efisiensi transformasi melalui perantara Agrobacterium pada $N$. tabacum mencapai $92 \%$ dan pada $N$. bentamiana mencapai 82\%, sedangkan Anggraito (2012) mendapatkan efisiensi transformasi hanya $34,6 \%$ dalam mengintroduksikan gen $M a M t 2$.

Salah satu tanaman target untuk direkayasa genetiknya adalah Jatropha curcas. J. curcas merupakan salah satu pilihan sumber utama biodiesel, karena tidak berkompetisi manfaatnya sebagai pangan (Makkar \& Becker, 2009) dan memiliki manfaat ekologis (Fairless, 2007). Namun demikian, J. curcas dinilai kurang kompetitif dikembangkan di lahan yang subur, sehingga pengembangan tanaman ini diarahkan ke lahan-lahan marginal dengan kandungan aluminium tinggi. Dari penelitian pertama diketahui bahwa pertumbuhan J. curcas menurun akibat cekaman aluminium (Tistama et al. 2012).

Upaya untuk meningkatkan toleransi tanaman terhadap aluminium dapat dilakukan dengan mengintroduksi gen $C S$ (de la Fuente et al. 1997). Penelitian ini bertujuan mengintroduksikan gen $P a C S$ ke dalam tanaman tembakau dan beberapa aksesi $J$. curcas untuk meningkatkan sintesis dan sekresi sitrat sebagai agen pengkelat aluminium.

\section{METODE PENELITIAN}

Bahan untuk penelitian ini meliputi gen PaCS yang dikonstruksi ke dalam plasmid pMSH1 sebagai vector ekspresi (Gambar 1) dan Agrobacterium tumefaciens LB 4404 sebagai perantara transformasi. Tanaman model yang digunakan untuk menguji ekspresi gen adalah Nicotiana tabacum, dan Jatropha curcas sebagai tanaman target untuk ditingkatkan toleransinya terhadap cekaman aluminium. Primer $35 \mathrm{~S}$ forward (5'AAACCTCCTC-GATTCCATT3') dan PaCS reverse (5'TCAGCCGCGATCCTTGAGGGC3') digunakan untuk menganalisis integrasi transgen $P a C S$ di dalam tanaman transgenik.

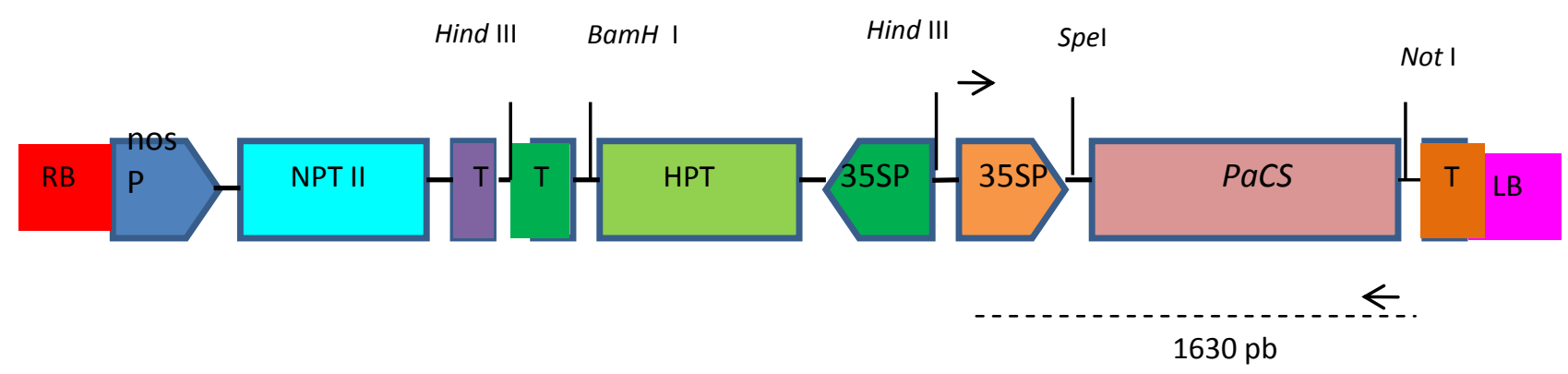

Gambar 1. Kontruksi gen PaCS di vektor ekspresi pMSH1 di sisi pemotongan Spe I dan Not I . 


\section{Introduksi gen PaCS ke N. Tabacum}

Introduksi gen mengikuti metode Anggaraito (2012). Daun N. tabacum dipotong kurang lebih $1 \mathrm{~cm}^{2}$ sebanyak 50 eksplan. Potongan daun direndam di dalam medium cair Murashige dan Skoog (MS) (Murashige \& Skoog 1962) yang mengandung $A$. tumefaciens $\left(\mathrm{OD}_{600}=0,4-0,6\right)$ dan $20 \mu \mathrm{M}$ asetosiringon, selama 10 menit. Daun ditanam pada media kokultivasi yaitu medium padat MS yang diperkaya dengan 1 ppm BAP dan $20 \mu \mathrm{M}$ asetosiringon, dan diseleksi dengan higromisin dan kanamisin. Tanaman yang mengandung sisipan promotor dan gen $\mathrm{PaCS}$ disebut sebagai tanaman transgenik T1. Tanaman transgenik $\mathrm{T} 1$ diaklimatisasi dan ditanam di pot hingga menghasilkan biji.

\section{Uji Tantang Tanaman Transgenik terhadap Higromisin dan Cekaman Aluminium}

Benih tembakau tipe liar (TL) dan transgenik T1 disterilisasi dengan $70 \%$ alkohol selama 1 menit, kemudian benih dikecambahkan selama 1 minggu pada kondisi gelap di media MS0 dengan dan tanpa ditambahkan 50 ppm higromisin. Setelah benih berkecambah, kultur dipindahkan ke kondisi terang. Setelah 1 minggu di kondisi terang, jumlah tanaman yang berkecambah normal dan biji yang tidak berkecambah atau berkecambah tetapi tidak normal pertumbuhannya dihitung. Respon biji T1 terhadap higromisin diuji dengan Chi kwadrat untuk menentukan pola segregasinya.

Kecambah yang lolos seleksi higromisin diaklimatisasi dan dikultur hidroponik menggunakan media $1 / 2$ konsentrasi MS, $\mathrm{pH} 6$ dan ditumbuhkan selama 1 minggu dengan aerasi. Tanaman tipe liar diperlakukan sama dengan tanaman transgenik. Setelah diadaptasi di medium pH 4 selama 3 hari, tanaman diperlakuan dengan $300 \mu \mathrm{M} \mathrm{Al}$ dalam media $1 / 4 \mathrm{MS} 0 \mathrm{pH} 4$ selama 6 hari dan diberi aerasi. Konsentrasi aluminium tersebut telah digunakan untuk menyeleksi tembakau transgenik MmSOD (Hanum 2012). Media diganti setiap dua hari dan panjang akar diukur pada hari ke 0, 2, 4 dan ke 6.
Introduksi Gen PaCS ke Jatropha curcas dengan di Mediasi oleh A. tumefaciens

Introduksi gen $\mathrm{PaCS}$ ke tanaman $J$. curcas mengikuti metode Li et al. (2007), dengan sumber eksplan dari kotiledon. Eksplan yang berkalus dipindahkan ke dalam medium MIK ditempatkan pada kondisi cahaya 2000 lux dan ditambah dengan $200 \mathrm{mg} / \mathrm{l}$ cefotaksim dan $20 \mathrm{mg} / \mathrm{l}$ kanamisin. Jumlah tunas yang muncul dihitung pada 1 bulan pertama dan kedua setelah 2 bulan perlakuan. Tunas yang hidup pada media seleksi ini kemudian dipindahkan ke dalam media 1/2 MS, yang diperkaya dengan 20 ppm IBA, 100 $\mu 1 / \mathrm{L}$ 0,1 $\mathrm{M} \mathrm{AgNO}_{3}$ : Na Thiofosfat (1:4), dan disubkultur setiap 10 hari.

\section{Deteksi Tanaman Transgenik}

Gen $\mathrm{PaCS}$ yang tersisip ke jaringan tanaman dianalisis menggunakan primer $35 \mathrm{~S}$ forward dan PaCS reverse. Kondisi PCR diatur sebagai berikut: pre PCR $95^{\circ} \mathrm{C}$ selama 4 menit, denaturasi $94{ }^{\circ} \mathrm{C}$ selama 30 detik, annealing pada suhu $55{ }^{\circ} \mathrm{C}$ selama 45 detik, pemanjangan pada suhu $72{ }^{\circ} \mathrm{C}$ selama 2 menit, siklus ini diulang $40 \mathrm{kali}$, dan pasca PCR $72{ }^{\circ} \mathrm{C}$ selama 5 menit dan suhu $20{ }^{\circ} \mathrm{C}$ selama 5 menit. Deteksi hpt menggunakan primer forward 5'GATGGTTGGCGACCTCGTATT3' dan reverse 5'GATGTAGGA-GGGCGTGGATA3'. Kondisi PCR sebagai berikut Pre PCR $95^{\circ} \mathrm{C}$ selama 4 menit, denaturasi $94{ }^{\circ} \mathrm{C}$ selama 30 detik, anneling pada suhu $60{ }^{\circ} \mathrm{C}$ selama 45 detik, pemanjangan pada suhu $72^{\circ} \mathrm{C}$ selama 1 menit, siklus ini diulang $40 \mathrm{kali}$, dan pasca PCR pada 72 ${ }^{\circ} \mathrm{C}$ selama 5 menit dan suhu $20{ }^{\circ} \mathrm{C}$ selama 5 menit.

\section{HASIL DAN PEMBAHASAN}

\section{Introduksi PaCS ke tanaman model Nicotiana tabacum}

Tiga plantlet $N$. tabacum lolos seleksi terhadap medium MS yang mengandung diperkaya $30 \mu \mathrm{g} / \mathrm{ml}$ higromisin. Ketiga galur tersebut diduga telah tersisip gen hpt yang merupakan bagian dari konstruksi gen PaCS. Hasil PCR dengan kombinasi primer gen $\mathrm{PaCS}$ dengan promoter $35 \mathrm{~S}$ menunjukkan bahwa hanya satu galur yang 
mempunyai pita DNA berukuran 1630 pb. Sisipan tersebut dapat dipastikan merupakan konstruksi yang diintroduksikan ke dalam tanaman tembakau dengan ukuran $1630 \mathrm{pb}$, karena sam ukurannya dengan ukuran gen PaCS dalam pMSH1(Gambar
2). Tembakau tipe liar dan dua galur lainnya tidak mengandung sisipan gen PaCS. Tembakau transgenik $P a C S$ ditanam di pot hingga menghasilkan biji.

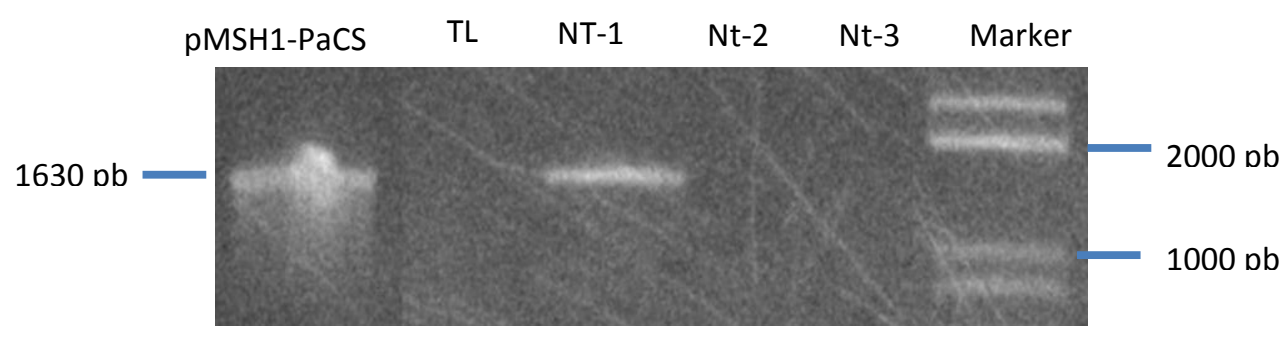

Gambar 2. Hasil PCR dari tiga galur tembakau yang diduga transgenik yaitu Nt-1, Nt-2 dan Nt-3 dengan kontrol negatif tembakau tipe liar (TL) dan pMSH1-PaCS sebagai kontrol positif.

Biji transgenik pertama (T1) diseleksi untuk membedakan biji transgenik dan non-transgenik dengan menumbuhkan pada media yang mengandung $50 \mu \mathrm{g} / \mathrm{ml}$ higromisin (Hannum 2012; Anggraito 2012). Kecambah biji tembakau transgenik sebagian besar tumbuh normal pada 50 $\mu \mathrm{g} / \mathrm{ml}$ higromisin dan hanya sebagian kecil tumbuh kerdil. Tanaman yang tumbuh normal mengandung gen $h p t$ yang mengatur toleransi terhadap higromisin, sedangkan biji yang tidak mengandung gen tersebut mengalami penghambatan pertumbuhan (Gambar 3).

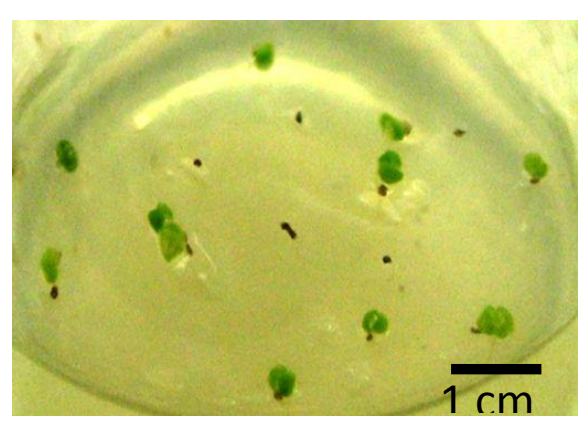

a

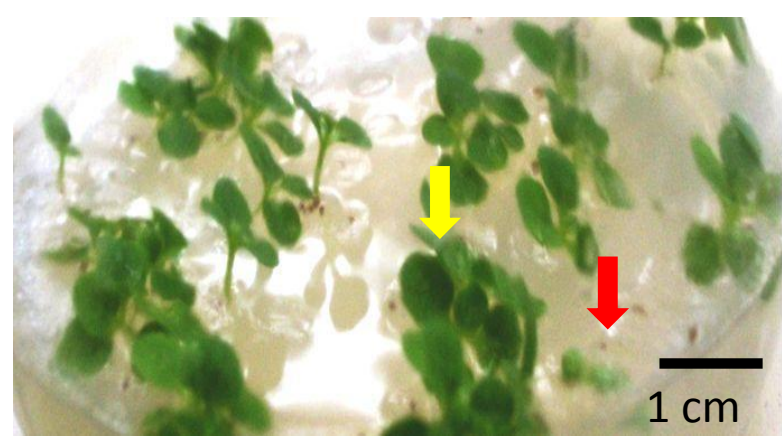

b

Gambar 3. Seleksi tanaman tembakau menggunakan medium MS yang ditambahkan $50 \mu \mathrm{g} / \mathrm{ml}$ higromisin. Semua biji tembakau tipe liar (TL) terhambat perkecambahannya (a), dan T1 (b) sebagian besar tumbuh normal. Tanda kuning menunjukan tanaman yang toleran terhadap higromisin (transgenik), dan panah merah menunjuk ke tanaman yang peka terhadap higromisin (non transgenik).

Pengujian toleransi 150 biji T1 terhadap higromisin diperoleh 126 benih dapat berkecambah media tersebut. Jumlah biji yang berkecambah dapat tumbuh normal sebanyak 96 biji, sementara pertumbuhan 30 kecambah lainnya mengalami penghambatan dan kerdil. Hasil analisis Chi kuadrat menunjukkan bahwa segregasi NT1 adalah 3:1 (toleran : peka) terhadap higromisin. Segregasi tanaman 3:1 menunjukkan bahwa gen hpt telah terintegrasi di dalam genom tanaman tembakau, dan diwariskan ke generasi berikutnya mengikuti Hukum Mendel. Tanaman transgenik T0 adalah heterozigot untuk hpt. Tanaman yang toleran terhadap higromisin diaklimatisasi dan di kultur hidroponik dengan menggunakan $1 / 2$ konsentrasi media MS pada $\mathrm{pH}$ 
5,8 selama 1 minggu. Hasil aklimatisasi diperoleh 57 tanaman yang mempunyai pertumbuhan yang baik. Kelima puluh tujuh tanaman ini selanjutnya diuji tantang dengan larutan media yang mengandung aluminium.

\section{Uji Tantang Tanaman T1 terhadap Cekaman Al}

Pemanjangan akar tembakau tipe liar (TL) dan sebagian besar tanaman transgenik mengalami penghambatan setelah dicekam dengan $300 \mu \mathrm{M}$ Al. Pertambahan panjang akar tembakau TL pada hari ke-2, 4, dan 6 berturut adalah rata-rata $0,2 \mathrm{~cm}$ dan $0,12 \mathrm{~cm}$, dan $0,04 \mathrm{~cm}$. Lima tanaman dari 57 tanaman transgenik yang diuji masih tumbuh dengan normal setelah 7 hari mendapat cekaman Al. Kelima tanaman tersebut adalah tanaman transgenik yang toleran terhadap cekaman Al. Rata-rata pertambahan panjang akar kelima tanaman yang toleran Al (NT1) tersebut pada hari ke 2, 4, dan 6 adalah berturut-turut $0,48 \mathrm{~cm}, 0,40$ dan 0,29 cm (Gambar 4). Laporan Delhaize et al. (1993) menyebutkan bahwa tanaman Triticum sativum yang peka hampir tidak ada pemanjangan akar lagi setelah 1 hari dicekam oleh $\mathrm{Al}$, demikian juga dengan Pisum sativum (Yamamoto et al. 2001). Dengan demikian, pertambahan akar kelima tanaman transgenik menunjukkan bahwa gen $\mathrm{PaCS}$ meningkatkan toleransi tanaman tembakau.
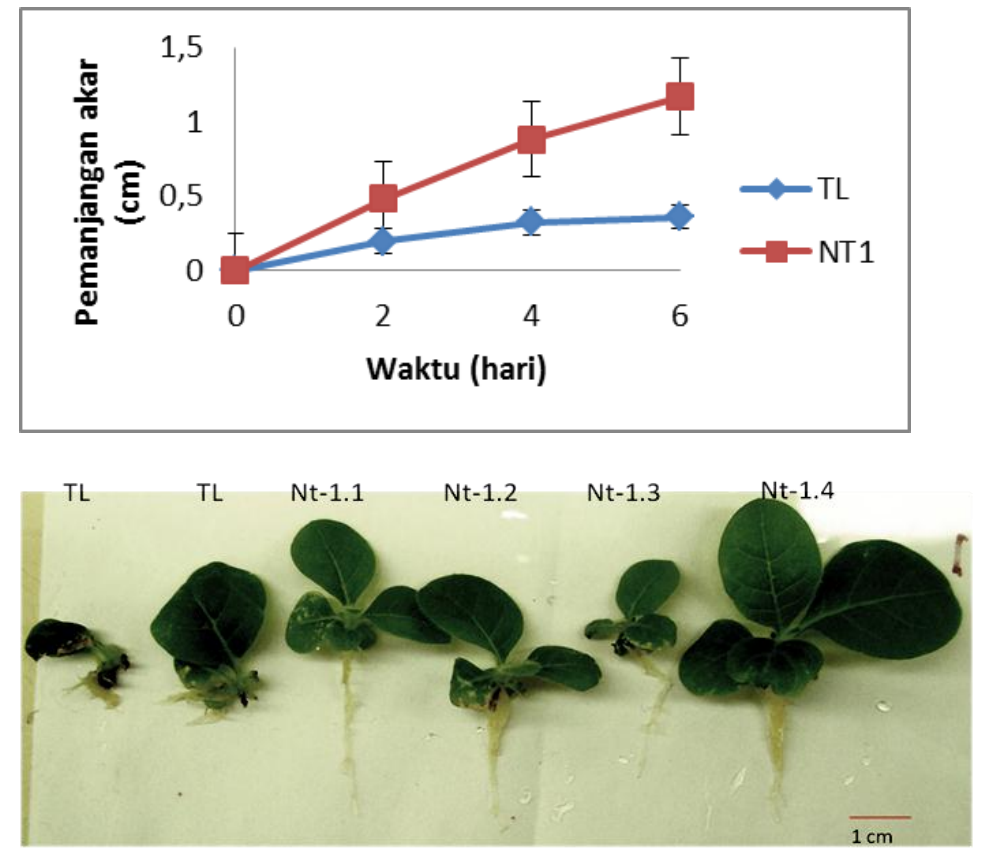

Gambar 4. Pemanjangan akar N. tabacum tipe liar (TL) dan tanaman transgenik T1 yang mendapat cekaman $300 \mu \mathrm{M} \mathrm{Al}$ dalam $1 / 4$ konsentrasi medium MS. Bar menunjukkan SE dengan $\mathrm{n}=5$. Fenotipe akar tanaman tembakau setelah mendapat cekaman Al selama 7 hari.

Pemanjangan akar ditentukan oleh aktivitas pembelahan sel-sel di daerah meristem dan diikuti pemanjangan sel-sel di zona pemanjangan (Ryan et al. 1993). Penghambatan aktivitas pemanjangan akar oleh Al pada varietas sensitif lebih tinggi dibandingkan dengan varietas toleran. Hal ini telah dilaporkan seperti pada tanaman jagung (Boscolo et al. 2003), dan gandum (Ma et al. 2004). Tamas et al. (2006) melaporkan bahwa cekaman Al selama dua hari menyebabkan penetrasi $\mathrm{Al}$ mencapai bagian luar korteks dan pada hari ketiga penetrasi telah mencapai sebagian besar endodermis. Penghambatan akar terjadi karena $\mathrm{Al}$ memicu terbentuknya reactive oxygen species (ROS), menghambat respirasi dan menipiskan ketersediaan ATP dalam sel (Yamamoto et al. 2002) dan ROS yang terbentuk menyebabkan degradasi lipid penyusun membran sel(Yamamoto et al. 2001). 


\section{Analisis Histologi Akar Tanaman Transgenik}

Akumulasi Al di ujung akar T1 relatif lebih rendah daripada tipe liarnya. Hal ini ditunjukan oleh adanya intensitas pewarnaan hematoksilin yang lebih kuat pada akar TL dibandingkan akar tanaman transgenik. Pewarnaan hematoxilin dapat mengikat Al sehingga berwarna keunguan. Akumulasi Al yang tinggi di tanaman TL menyebabkan kerusakan sel-sel pada jaringan ujung akar yang ditunjukkan dengan pewarnaan
Evans blue (Gambar 5). Evans blue digunakan sebagai pengukur integritas membran plasma. Warna biru pada sitoplasma dikaitkan dengan kerusakan dan kematian sel (Delisle et al. 2001). Akumulasi Al dan kerusakan akar pada galur toleran relatif lebih rendah dibandingkan TL. Sekresi sitrat akar tanaman transgenik diduga lebih tinggi dibandingkan TL. Sekresi sitrat akan mengkelat $\mathrm{Al}$ dan membentuk komplek Al-sitrat untuk mencegah masuk ke dalam sel (Anoop et al. 2003). Xue et al. (2006) membuktikan bahwa eksudasi sitrat mengurangi penghambatan akar oleh cekaman Al.
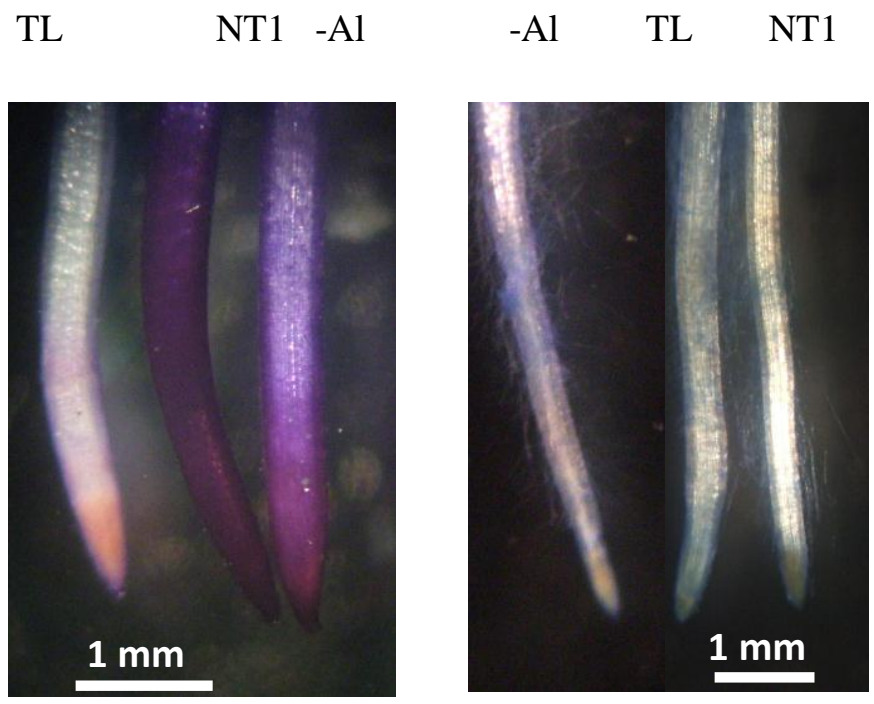

Gambar 5. Pewarnaan akar tanaman tembakau tipe liar dan tanaman transgenik T1 mendapat cekaman 300 $\mu \mathrm{M}$ selama 7 hari dengan hematoksilin (kiri), dan pewarnaan Evans blue (kanan). TL: tanaman tipe liar, Nt1: tanaman transgenik $\mathrm{T} 1,-\mathrm{Al}$ : tanpa perlakuan $\mathrm{Al}$.

\section{Introduksi gen PaCS ke dalam Jatropha curcas}

Kalus kotiledon $J$. curcas mulai terbentuk pada hari ke-15 hingga 20 setelah tanam dan pertumbuhannya mencapai maksimal pada 45 hari setelah tanam. Persentase kalus yang terbentuk pada eksplan IP 3A, IP 3M dan IP 2P yang tidak diperlakukan dengan Agrobacterium berturut-turut $59,25 \%, 76,79 \%$, dan $66,67 \%$ dari jumlah eksplan yang ditanam. Sedangkan eksplan yang dikokultivasi dengan Agrobacterium menghasilkan persentase kalus $64 \%, 69,51 \%$, dan $58,19 \%$ berturut-turut untuk eksplan IP 3A, IP 3M, IP 2P (Tabel 2). Mitchel et al. (2008) melaporkan bahwa tiap genotipe dan jenis eksplan mempunyai respon yang berbeda dalam menghasilkan kalus pada media dasar yang sama.

Penurunan jumlah eksplan yang berkalus pada eksplan yang dikokultivasi dengan $A$. tumefaciens berkisar $36,7 \%$. Tidak semua kalus dapat menghasilkan tunas pada medium seleksi yang mengandung $20 \mu \mathrm{g} / \mathrm{ml}$ kanamisin (Tabel 2). Persentase tunas yang terbentuk yang toleran kanamisin dari aksesi IP 3A, IP 3M dan IP 2P adalah $12,88 \%, 10,26 \%$ dan $12,5 \%$ dari rata-rata tunas pada media tanpa antibiotik. Jumlah tunas toleran ini masih lebih rendah daripada penelitian sebelumnya. Li et al. (2007)) mampu mendapatkan tunas yang toleran sebanyak 15-20\%. Kemungkinan hal ini disebabkan perbedaan 
genotipe yang digunakan dalam penelitian ini. Jumlah kalus lolos seleksi toleran terhadap kanamisis pada IP 3A dan IP 2P berturut-turut sebanyak 96 dan 103 kalus.

Tunas-tunas in vitro dipindahkan ke medium pengakaran selama 20 hari. Beberapa tunas yang masih bertahan hidup dipindahkan ke media $1 / 2$ MS tanpa zat pengatur tumbuh. Jumlah tunas yang bertahan pada media $1 / 2$ MS sebanyak 10 tunas dari aksesi IP 3A, 10 dari aksesi IP3M dan 9 dari aksesi IP 2P. Dari 10 tunas tersebut hanya ada
4 tunas yang dapat berakar atau $40 \%$ tunas dapat berakar. Media perakaran diperkaya dengan 20 ppm BAP dan AgNO3 cukup efektif untuk menginduksi perakaran tanaman jarak. Penelitian Pan et al. (2010) hanya mendapat satu planlet dari 120 tunas in vitro. Kajikawa et al. (2012) telah memperbaiki sistem transformasi genetik pada $J$. curcas dengan efesiensi mencapai $4,3 \%$ yang menggunakan bispyribac sebagai bahan penyeleksinya.

Tabel 2. Jumlah tunas dari masing-masing aksesi J.curcas tanpa perlakuan Agrobacterium dan tunas terduga transgenik.

\begin{tabular}{lcccc}
\hline & $\begin{array}{c}\text { Jumlah } \\
\text { Eksplan }\end{array}$ & $\begin{array}{c}\text { Jumlah } \\
\text { Kalus }\end{array}$ & $\begin{array}{c}\text { Jumlah } \\
\text { Tunas }\end{array}$ & $\begin{array}{c}\text { Rata-rata } \\
\text { tunas/eksplan }\end{array}$ \\
\hline Kontrol IP 3A & 54 & 32 & 62 & 1.94 \\
Kontrol IP 3M & 56 & 43 & 67 & 1,56 \\
Kontrol IP 2P & 54 & 36 & 49 & 1,36 \\
Transgenik IP 3A & 150 & 96 & 24 & 0,25 \\
Transgenik IP 3M & 164 & 114 & 18 & 0,16 \\
Transgenik IP 2P & 177 & 103 & 17 & 0,17 \\
\hline
\end{tabular}
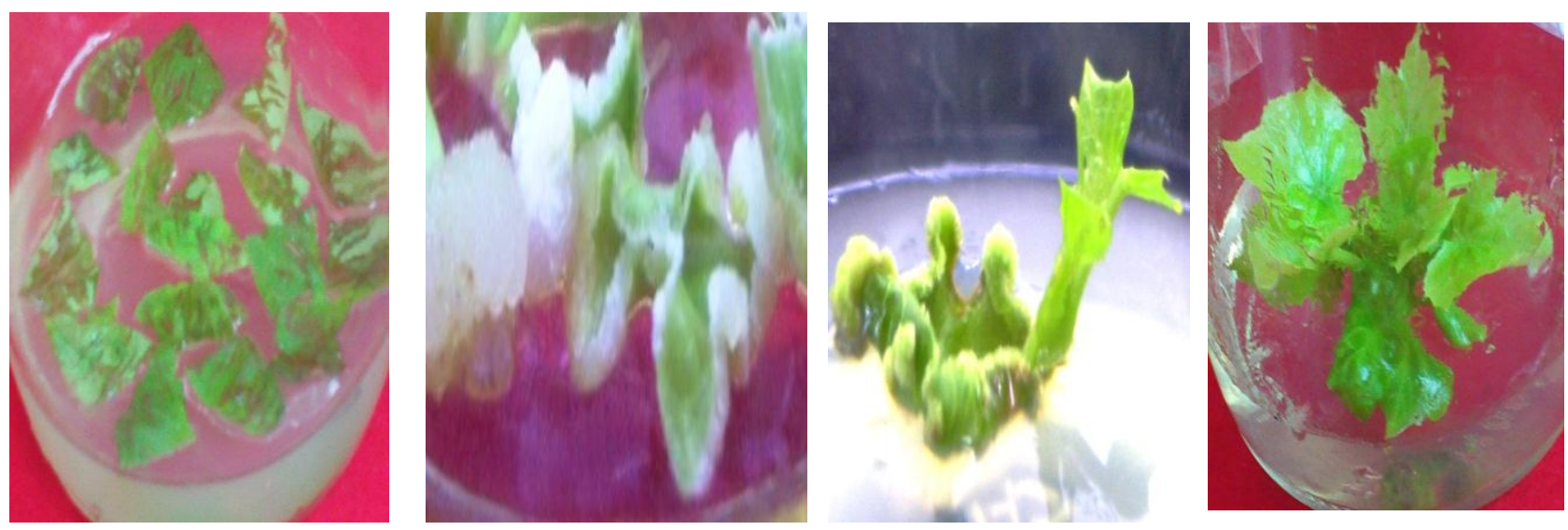

Gambar 6. Proses introduksi gen PaCS ke J. curcas dengan perantara Agrobacterium tumefaciens. Infeksi eksplan kotiledon dengan A. tumefaciens (a). Kokultivasi eksplan dengan A. tumeaciens selama 3 hari (b). Induksi kalus menggunakan media MIK yang mengandung 200 ppm cefotaksim (c), di kondisi gelap. Induksi tunas menggunakan media MIK dengan agen seleksi $20 \mu \mathrm{g} / \mathrm{ml}$ kanamisin (d). Pemanjangan tunas di media yang mengandung $0,5 \mathrm{ppm} \mathrm{GA}_{3}$ (e). Induksi pengakaran menggunakan media yang mengandung 20 ppm IBA (f).

\section{Analisis Integrasi Gen hpt dan Promoter-PaCS di dalam Genom Tanaman Trasngenik}

Konfirmasi tanaman yang lolos seleksi dari kanamisin dilakukan dengan menggunakan primer gen $\mathrm{PaCS}$, primer spesifik ketahanan higromisin dan primer kombinasi $35 \mathrm{~S}$ CaMV 
forward dengan $\mathrm{PaCS}$ reverse. Planlet yang diuji sebanyaki 27 planlet transgenik yaitu 12 tunas IP 3A, 15 tunas dari IP 3M, dan 11 tunas IP 2P. Primer spesifik gen $\mathrm{PaCS}$ menunjukkan bahwa semua tunas menghasilkan pita berukuran $1300 \mathrm{pb}$ termasuk tipe liarnya. Diduga J. curcas mempunyai gen famili sitrat sintase yang sekuennya mirip dengan PaCS (Gambar 7 a). PCR menggunakan primer spesifik gen $h p t$ menunjukkan 4 planlet IP 3A, 4 planlet IP 3M dan 3 planlet IP 2P mengandung gen hpt yang berukuran $600 \mathrm{pb}$, sedangkan tipe liar (TL) tidak mempunyai gen tersebut (Gambar 7 b). Karena posisi gen $h p t$ di sisi kiri (up stream) dari $n p t$ di dalam T-DNA maka dipastikan bahwa eksplaneksplan tersebut mengandung gen ketahanan terhadap kanamisin. Analis PCR terhadap eksplan yang mengandung $\mathrm{PaCS}$ menggunakan kombinasi primer 35S CaMV $\mathrm{F}$ dengan primer $\operatorname{PaCS} \mathrm{R}$ menunjukkan bahwa hanya ada dua eksplan yang mengandung gen $\mathrm{PaCS}$ yaitu A1 dan P7 (Gambar 7 c). Jumlah tanaman transgenik PaCS yang diperoleh jika dibandingkan dengan jumlah kalus yang lolos seleksi kanamisin hanya berkisar $1 \%$.
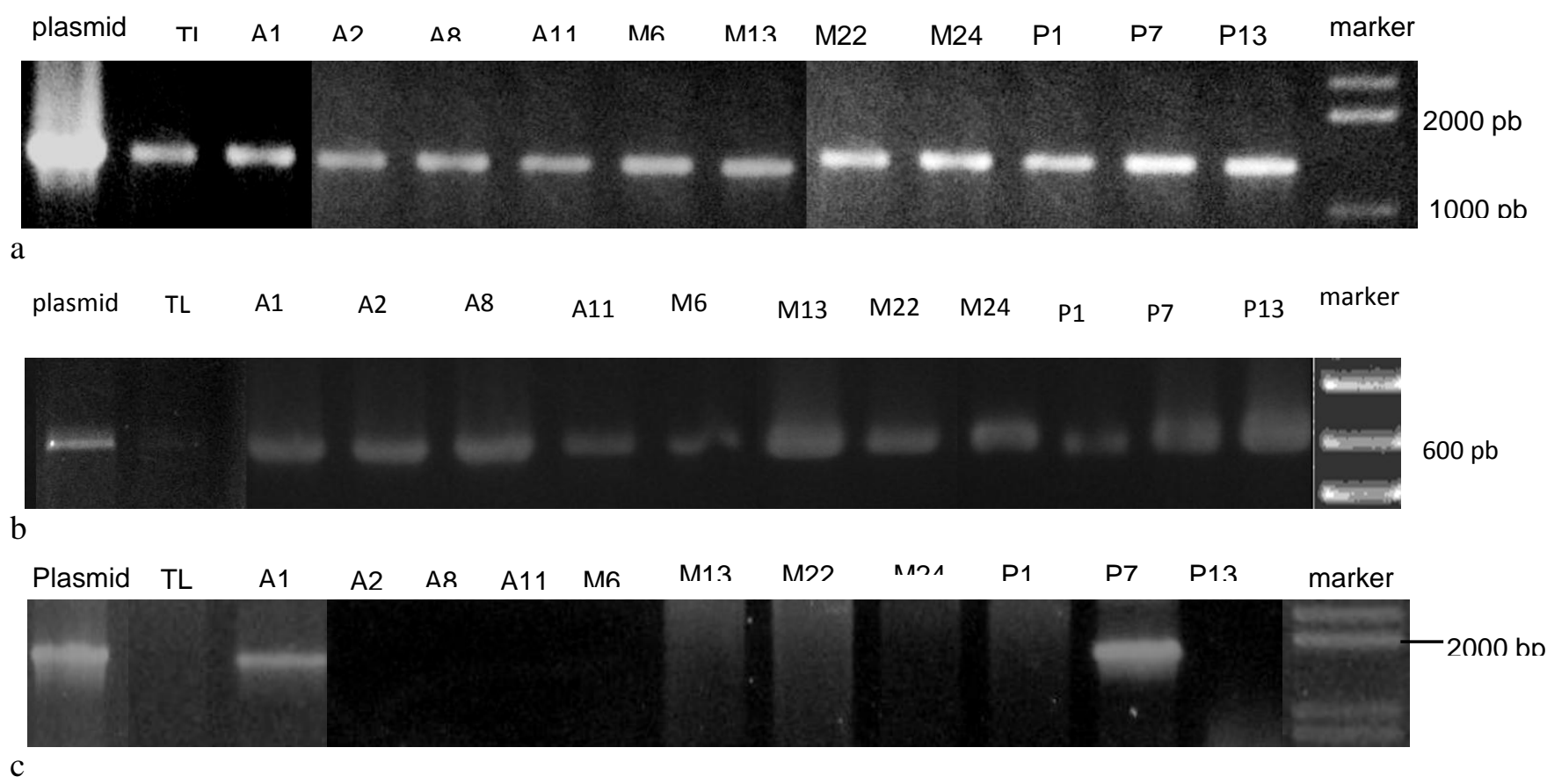

Gambar 7. Hasil PCR terhadap tunas transgenik yang terdiri 4 galur IP 3A, 4 galur IP 3M dan 3 galur dari IP 3P. PCR menggunakan primer spesifik gen PaCS, semua galur menghasilkan pita $1300 \mathrm{pb}$ (a), menggunakan primer $h p t$ menghasilkan semua galur transgenik mengandung gen resistensi antibiotik higromisin (b), dan menggunakan primer promoter 35S CaMV forward dan PaCS reverse menghasilkan pita berukuran 1650 pb hanya pada 2 galur yang transgenik yaitu A1 dan P7 (c).

\section{KESIMPULAN}

Gen PaCS berhasil diintroduksikan ke dalam genom tanaman Nicotiana tabacum dan $J$. curcas dengan bantuan A. tumefaciens. Tanaman tembakau transgenik $P a C S$ di bawah kendali promoter $35 \mathrm{~S}$ CaMV dapat mengurangi penyerapan aluminium ke dalam akar sehingga meningkatkan toleransinya terhadap cekaman Al. Gen tersebut diturunkan ke generasi berikutnya mengikuti hukum Mendel. Introduksi gen $\mathrm{PaCS}$ ke $J$. curcas masih rendah yaitu $1 \%$ dari total eksplan yang ditranformasi. Introduksi gen pelapor $h p t$ tidak selalu diikuti introduksi gen target $\mathrm{PaCS}$.

\section{DAFTAR PUSTAKA}

Anggraito YU. 2012. Transformasi genetik Nicotiana bentamiana L. dan kedelai dengan gen MaMt 2 penyandi metalothionein tipe II dari Melastoma malabathricum L. [Disertasi]. Sekolah Pascasarjana, Institut Pertanian Bogor. Bogor. 
Anoop VM, Basu U, McCammon MT, McAlisterHenn L, Taylor GJ. 2003. Modulation of citrate metabolism alters aluminium tolerance in yeast and transgenic canola overexpressing a mitochondrial citrate synthase. Plant Physiol 132: 2205-2217.

Barone P, Rosellini D, LaFayette P, Bouton J, Veronesi F, Parrott W. 2008. Bacterial citrate synthase expression and soil aluminum tolerance in transgenic alfafa. Plant Cell Rep 27: 893-901.

Boscolo PRS, Menossi M, Jorge RA. 2003. Aluminum-induced oxidative stress in maize. Phytochem 62: 181-189.

Buch AB, Archana G, Naresh-Kumar G. (2008). Metabolic channeling of glucose towards gluconate in phosphate-solubilizing Pseudomonas aeruginosa P4 under phosphorus deficiency. Res Microbiol 159: 635-642.

Chin-A-Woeng TFC, Bloemberg GV, Lugtenberg BJJ. 2003. Phenazine and their role in bicontrol by Pseudomonas bacteria. New Phytol 157: 503-523.

de la Fuente JM, Ramire-Rondriguez V, CabreraPonce JL, Harrere-Estrell L. 1997. Aluminum tolerance in transgenic plant by alteration of citrate synthesis. Science 276: 1566-1568.

Delhaize E, Craig S, Beaton CD, Bennet RJ, Jagadish VC, Randall PJ. 1993. Aluminum tolerance in wheat (Triticum aestivum L). I. Uptake and distribution of Aluminum in root apices. Plant Physiol 103: 685-693.

Delisle G, Champoux M, Houde M. 2001. Characterization of oxalate oxidase and cell death in Al-sensitive and tolerant wheat roots. Plant Cell Physiol 42(3): 324-333.

Deng W, Luo K, Li Z, Yang Y, Hu N, Wu H. 2009. Overexpression of Citrus junos mitochondrial citrate synthase gene in Nicotiana benthamiana confers aluminum tolerance. Planta 230(2): 355-365.

Hannum S. 2012. Ispolasi, pengklonan, dan analisis ekspresi gen penyandi copper-zinc superoxide dismutase (CuZn-SOD) dari
Melastoma malabathricum L. [Disertasi]. Sekolah Pascasarjana Institut Pertanian Bogor. Bogor.

Hassett DJ, Woodruff WA, Wozniak DJ, Vasil ML, Cohen MS, Ohman DE. 1993. Cloning and characterization of the Pseudomonas aeruginosa $\operatorname{sod} \mathrm{A}$ and $\operatorname{sod} \mathrm{B}$ genes encoding manganese- and iron- cofactored superxide dismutase: Increased manganese superoxide dismutase activity in alginate-producing bacteria. J of Bacteriol : 7668-7665.

Kajikawa M, Morikawa K, Inoue M, Widyastuti U, Suharsono S, Yokota A, Akashi K. 2012. Establishment of biopyribac selection protocols for Agrobacterium tumefaciens dan Agrobacterium rhizogenes-mediated transformation of the oil seed plant Jatropha curcas. Plant Biothecnol 29: 145-153

Kochian LV, Pence NS, Letham DLD, Pineros MA, Magahaes JV, Hoekenga OA, Garvin DF. 2002. Mechanisms of metal resistance in plants: aluminum and heavy metals. Plant and Soil 247: 109-119.

Koyama H, Kawamura A, Kihara T, Hara T, Takita E, Shibata D. 2000. Overexpression of mitochondrial citrate synthase in Arabidopsis thaliana improved growth on phosphorous limited soil. Plant Cell Physiol 41: 1030-1037.

Lemire J. Mailloux R, Auger C, Whalen D, Appana VD. 2010. Pseudomonas fluorescens orchestrates a fine metabolicbalancing act to counter aluminum toxicity. Envir Microb 12(6): 1384-1390.

Li M, Li H, Jiang H, Pan X, Wu X. 2007. Establishment of an Agrobacteriummediated cotyledone disc transformation method for Jatropha curcas. Plant Cell Tiss Org Cult :173-181.

Ma J F, Nagao S, Sato K, Ito H, Furukawa J, Takeda K. (2004). Molecular mapping of a gene responsible for Al-activated secretion of citrate in barley. J Exp Bot 55: 13351341.

Mailloux RJ, Lemire J, Kalyuzhnyi S, Appanna V. 2008. A novel metabolic network leads to enhanced citrate biogenesis in Pseudomonas 
flourescens exposed to aluminum toxicity. Extremophiles 12: 451-459.

Makkar HPS, Becker K. 2009. Jatropha curcas, a promising crop for the generation of biodiesel and value-added cproducts. Eur $J$ Lipid Sci technol 111: 773-787

Murashige T, Skoog F. 1962. A revised medium for rapid growth and bioassay with tobacco tissue culture. Plant Physol 15: 473-497.

Pan J, Fu Q, Xu ZF. 2010. Agrobacterium tumefaciens-mediated transformation of biofuel plant Jatropha curcas using kanamicin selection. Afric J Biotec 2(39): 6477-6481.

Poschenrieder C, Gunse B, Corrales I, Barchelo J. 2008. A glance into aluminum toxicity and resistance in plants. Sci of the Tot Envir: 356-368.

Ryan PR, Ditamaso JM, Kochian LV. 1993. Aluminum toxicity in root: an investigation of spatial sensitivity and of the root cap. $J$ Exp Bot 44: 437-446.

Tamas L, Budikova S, Simonovicova M, Huttova J, Siroka B, Mistrik I. 2006. Rapid and simple method for Al-toxicity analysis in emerging barley roots during germination. Biol Plant 50(1): 87-93.

Xue YJ, Xie FL, Yang ZM. 2006. Negative regulation of aluminum-responsive citrate efflux from roots of Cassia tora by an anion channel antagonist. Bot Stud 47: 137-144.

Yamamoto Y, Kobayashi Y, Devi SR, Rikiishi S, Matsumoto H. 2002. Aluminum toxicity is associated with mitochondrial dysfunction and production reactive oxygen species in plant cells. Plant Physiol 128:63-72.

Yamamoto Y, Kobayashi Y, Matsumoto H. 2001. Lipid peroxidation is an early symptom triggered by aluminum, but not the primary cause of elongation inhibition in pea roots. Plant Physiol 125:199-208. 